\title{
Requirement for T-bet in the aberrant differentiation of unhelped memory $\mathrm{CD}^{+} \mathrm{T}$ cells
}

\author{
Andrew M. Intlekofer, ${ }^{1,2}$ Naofumi Takemoto, ${ }^{1,2}$ Charlly Kao, ${ }^{4}$ \\ Arnob Banerjee, ${ }^{1,2}$ Felix Schambach, ${ }^{1,2}$ John K. Northrop, ${ }^{3}$ Hao Shen, ${ }^{3}$ \\ E. John Wherry, ${ }^{4}$ and Steven L. Reiner ${ }^{1,2}$ \\ ${ }^{1}$ Abramson Family Cancer Research Institute, ${ }^{2}$ Department of Medicine, and ${ }^{3}$ Department of Microbiology, University \\ of Pennsylvania, Philadelphia, PA 19104 \\ ${ }^{4}$ Immunology Program, The Wistar Institute, Philadelphia, PA 19104
}

\begin{abstract}
Immunity to intracellular pathogens requires dynamic balance between terminal differentiation of short-lived, cytotoxic effector $\mathrm{CD}^{+} \mathrm{T}$ cells and self-renewal of central-memory $\mathrm{CD}^{+} \mathrm{T}$ cells. We now show that T-bet represses transcription of IL-7R $\alpha$ and drives differentiation of effector and effector-memory $\mathrm{CDB}^{+} \mathrm{T}$ cells at the expense of central-memory cells. We also found T-bet to be overexpressed in $\mathrm{CDB}^{+} \mathrm{T}$ cells that differentiated in the absence of $\mathrm{CD}^{+} \mathrm{T}$ cell help, a condition that is associated with defective central-memory formation. Finally, deletion of T-bet corrected the abnormal phenotypic and functional properties of "unhelped" memory CD8 ${ }^{+} \mathrm{T}$ cells. T-bet, thus, appears to function as a molecular switch between central- and effector-memory cell differentiation. Antagonism of T-bet may, therefore, represent a novel strategy to offset dysfunctional programming of memory $\mathrm{CD8}^{+} \mathrm{T}$ cells.
\end{abstract}

CORRESPONDENCE

Steven L. Reiner:

sreiner@mail.med.upenn.edu

Abbreviation used: LCMV, lymphocytic choriomeningitis virus.
When a naive $\mathrm{CD} 8^{+} \mathrm{T}$ cell encounters antigen, it undergoes vigorous clonal expansion and differentiation into a population comprised primarily of short-lived, cytotoxic effectors that undergo cell death after pathogen is cleared (1). The elimination of the antigen-experienced progeny of a selected $\mathrm{T}$ cell clone, however, is generally incomplete, ensuring preservation of a portion of daughter cells to provide a "memory" of the pathogen encounter. At least two functionally distinct classes of memory cells have been described, based on their pattern of tissue homing in the absence of antigen. Effector-memory $\mathrm{CD}^{+} \mathrm{T}$ cells provide protection against reinfection by patrolling peripheral tissues, but have a poor capacity for homeostatic renewal and secondary proliferation. Central-memory $\mathrm{CD}^{+}$ $\mathrm{T}$ cells, in contrast, recapitulate the surveillance behavior of their naive predecessor by migrating through secondary lymphoid organs; they are distinguished by efficient homeostatic renewal and rapid secondary proliferative responses to generate cytotoxic effectors upon reencounter with pathogen $(2,3)$. It remains controversial whether commitment to the self-renewing,

$\overline{\text { The online version of this article contains supplemental material. }}$ central-memory lineage occurs before or after adoption of the effector fate (3-6).

The intrinsic molecular program that directs commitment to the effector- versus centralmemory $\mathrm{CD}^{+} \mathrm{T}$ cell lineage is not fully understood. We found that deficiency of the transcription factor T-bet resulted in defective generation of effector-memory $\mathrm{CD} 8^{+} \mathrm{T}$ cells and excessive generation of central-memory $\mathrm{CD} 8^{+} \mathrm{T}$ cells. The enhanced central-memory formation resulting from T-bet deficiency directly contrasted with the defective central-memory formation occurring in the absence of $\mathrm{CD}^{+} \mathrm{T}$ cell help. Deletion of T-bet prevented the defective phenotypic and functional characteristics of unhelped $\mathrm{CD}^{+}$ $\mathrm{T}$ cells. These results suggest that T-bet may represent a novel target for manipulating the balance between terminal differentiation and self-renewal of pathogen-specific $\mathrm{CD} 8^{+} \mathrm{T}$ cells.

\section{RESULTS AND DISCUSSION}

T-bet represses IL-7R $\alpha$ in effector $\mathrm{CD}^{+} \mathrm{T}$ cells

During the acute phase of an infection, repression of IL-7R $\alpha$ marks pathogen-specific CD8 ${ }^{+}$ $\mathrm{T}$ cells destined for elimination, whereas the cells that will give rise to self-renewing memory 
$\mathrm{CD}^{+} \mathrm{T}$ cells seem to be contained within the IL-7R $\alpha-$ expressing subset $(7,8)$. When we examined the lymphocytic choriomeningitis virus (LCMV)-specific $\mathrm{CD}^{+} \mathrm{T}$ cell response in T-bet-deficient mice, we observed defective repression of IL-7R $\alpha$ at day 8 after infection (Fig. 1 A). Because this finding suggested that T-bet may function as a repressor of IL-7R $\alpha$, we tested whether T-bet was sufficient to repress IL-7R $\alpha$ in $\mathrm{T}$ cells. Retroviral-mediated expression of T-bet in $\mathrm{CD}^{+}$or $\mathrm{CD}^{+}{ }^{+} \mathrm{T}$ cells stimulated in vitro resulted in repression of IL-7R $\alpha$ mRNA (Fig. $1 \mathrm{~B}$ ). In addition, ectopic expression of T-bet in developing Th2 cells in which T-bet is not normally expressed resulted in repression of IL-7R $\alpha$ surface expression (Fig. 1 C).

The identification of $\mathrm{T}$-bet as a repressor of IL-7R $\alpha$ prompted us to test whether T-bet expression is associated with the IL-7R $\alpha^{\text {lo }}$ subset of effector $\mathrm{CD} 8^{+} \mathrm{T}$ cells. We sorted LCMV-specific P14 CD8 ${ }^{+} \mathrm{T}$ cells $8 \mathrm{~d}$ after infection on the basis of IL-7R $\alpha$ expression and examined T-bet mRNA. T-bet was enriched in the IL-7R $\alpha^{\text {lo }}$ subset of effector $\mathrm{CD}^{+}$ $\mathrm{T}$ cells, whereas the IL-7R $\alpha^{\text {hi }}$ subset had reduced expression of T-bet mRNA (Fig. 1 D) and protein (not depicted). A similar pattern of gene expression was observed in IL-7R $\alpha^{\text {hi }}$ and IL-7R $\alpha^{\text {lo }}$ cells from the endogenous LCMV-specific CD8 ${ }^{+}$ $\mathrm{T}$ cell response (not depicted).

In addition to elevated expression of T-bet, the IL-7R $\alpha^{\text {lo }}$ subset of effector $\mathrm{CD}^{+} \mathrm{T}$ cells exhibited substantial enrichment for KLRG1 mRNA (Fig. 1 D) and protein (not depicted). KLRG1 is an NK-like inhibitory receptor that marks replicative senescence in $\mathrm{CD}^{+} \mathrm{T}$ cells $(7,9)$ and whose expression in NK cells is dependent on T-bet (10). In contrast, IL-7R $\alpha^{\text {lo }}$ effectors had reduced expression of CCR 7 mRNA (Fig. $1 \mathrm{D})$, which is a chemokine receptor that represents a defining feature of central-memory $\mathrm{CD}^{+} \mathrm{T}$ cells $(2,3)$. In addition, we discovered that the IL-7R $\alpha^{\text {lo }}$ subset exhibited elevated expression of Blimp-1 mRNA (Fig. 1 D), a transcriptional repressor that promotes terminal differentiation of plasma cells (11) and that may also function in T lymphocytes $(12,13)$. Thus, enhanced expression of $\mathrm{T}$-bet appears to selectively mark IL-7R $\alpha^{\text {lo }}$ effector $\mathrm{CD}^{+} \mathrm{T}$ cells, which exhibit features of terminal differentiation and which have previously been shown to fail to give rise to self-renewing memory cells $(7,8)$.

Cell transfer experiments have suggested that the IL-7R $\alpha^{\text {lo }}$ subset of effector $\mathrm{CD}^{+} \mathrm{T}$ cells preferentially gives rise to effector-memory cells (7). Consistent with this potential lineage relationship, we found that $\mathrm{T}$-bet was enriched in effector-memory $\mathrm{CD}^{+} \mathrm{T}$ cells (Fig. 1, E and F). The skewing of T-bet expression in effector- versus central-memory cells was also recently reported in human memory $\mathrm{CD}^{+} \mathrm{T}$ cells (14). Given the variety of haploinsufficient phenotypes resulting from hemizygous deletion of $\mathrm{T}$-bet, it is possible that the differences in the amount of T-bet between IL-7R $\alpha^{\text {lo }}$ versus IL-7R $\alpha$ hi effectors and central- versus effector-memory $\mathrm{CD}^{+} \mathrm{T}$ cells could be functionally relevant (15-19). Expression of Blimp-1 paralleled that of T-bet, with elevated expression in the effector-memory $\mathrm{CD}^{+} \mathrm{T}$ cell subset (Fig. 1, E and F).
Eomes expression, in contrast, did not vary substantially between IL-7R $\alpha^{\text {hi }}$ and IL-7R $\alpha^{\text {lo }}$ (Fig. 1 D) or central- and effectormemory subsets (Fig. 1, E and F).

\section{T-bet deficiency results in enhanced generation of central- memory $\mathrm{CD}^{+} \mathrm{T}$ cells}

The expression pattern of $\mathrm{T}$-bet and its role in repressing IL-7R $\alpha$ suggested that $\mathrm{T}$-bet might negatively regulate the development of central-memory $\mathrm{CD}^{+} \mathrm{T}$ cells. We found that loss of $\mathrm{T}$-bet, in addition to causing derepression of IL-7R $\alpha$, resulted in effector $\mathrm{CD}^{+} \mathrm{T}$ cells that acquired several characteristics of central-memory cells, including high expression of CD27, low expression of KLRG1, and robust IL-2 production (Fig. 2, A and C) (16, 20). $30 \mathrm{~d}$ after infection, LCMV-specific $\mathrm{CD}^{+} \mathrm{T}$ cells from wild-type mice exhibited substantial heterogeneity (Fig. $2 \mathrm{~B}$ ), which is consistent with the presence of both central- and effector-memory $\mathrm{CD} 8^{+}$ $\mathrm{T}$ cells $(2,3,5)$. In contrast, $\mathrm{T}$-bet-deficient mice exhibited a predominance of central-memory $\mathrm{CD}^{+} \mathrm{T}$ cells (Fig. 2, $\mathrm{B}$ and $\mathrm{C})$. T-bet-deficient memory $\mathrm{CD}^{+} \mathrm{T}$ cells also exhibited a gene expression pattern similar to central-memory cells, with increased CCR7, reduced Blimp-1, and elevated Eomes mRNA (Fig. 2, D and E).

It was previously suggested that $\mathrm{T}$-bet functions as a positive regulator of memory $\mathrm{CD} 8^{+} \mathrm{T}$ cell development because T-bet-deficient mice were found to have decreased numbers of LCMV-specific memory CD8 ${ }^{+} \mathrm{T}$ cells in the blood and spleen (16). In the memory phase of the response $(30$ and $60 \mathrm{~d}$ after infection), we also found that $T b \times 21^{-/-}$mice had fewer LCMV-specific CD8 ${ }^{+} \mathrm{T}$ cells in the blood and spleen (Fig. $2 \mathrm{~F}$ and Fig. S1, available at http://www.jem.org/cgi/ content/full/jem.20070841/DC1). Despite the deficiency in the blood and spleen, Tb $\times 21^{-1-}$ mice were found to have increased numbers of memory cells in the lymph nodes. This might be partially attributable to the elevated expression of CCR7 in Tb $\times 21^{-1-} \mathrm{CD}^{+} \mathrm{T}$ cells (Fig. $2 \mathrm{D}$ ). To ensure that the phenotype of $\mathrm{T}$-bet deficiency was $\mathrm{CD}^{+} \mathrm{T}$ cell-intrinsic, we used a transfer system in which the behavior of both wildtype and $\mathrm{Tb} \times 21^{-/-} \mathrm{P} 14 \mathrm{CD}^{+} \mathrm{T}$ cells could be studied within the same wild-type host (Fig. S2). This system recapitulated the phenotypic, functional, and anatomic characteristics observed in the endogenous $\mathrm{CD}^{+} \mathrm{T}$ cell response of $\mathrm{Tb} \times 21^{-/-}$ mice. Together, these results suggest that $\mathrm{T}$-bet inhibits the formation of lymph node-homing, central-memory $\mathrm{CD}^{+}$ $\mathrm{T}$ cells and positively regulates the development of effectormemory $\mathrm{CD}^{+} \mathrm{T}$ cells.

Two features of central-memory $\mathrm{CD}^{+} \mathrm{T}$ cells are their robust capacity for secondary proliferation and an ability to confer heightened resistance to reinfection. Therefore, we assessed these characteristics in $\mathrm{Tb} \times 21^{-1-}$ memory $\mathrm{CD}^{+} \mathrm{T}$ cells by transferring equal numbers of GP33-specific wildtype or $\mathrm{Tb} \times 21^{-/-}$memory $\mathrm{CD}^{+} \mathrm{T}$ cells into naive wildtype recipients and challenging with Listeria monocytogenes expressing $\mathrm{GP}_{33-41}$. T-bet-deficient memory $\mathrm{CD}^{+} \mathrm{T}$ cells exhibited severalfold greater reexpansion than wild-type cells upon rechallenge (Fig. 3 A) and were found to express IL-2 

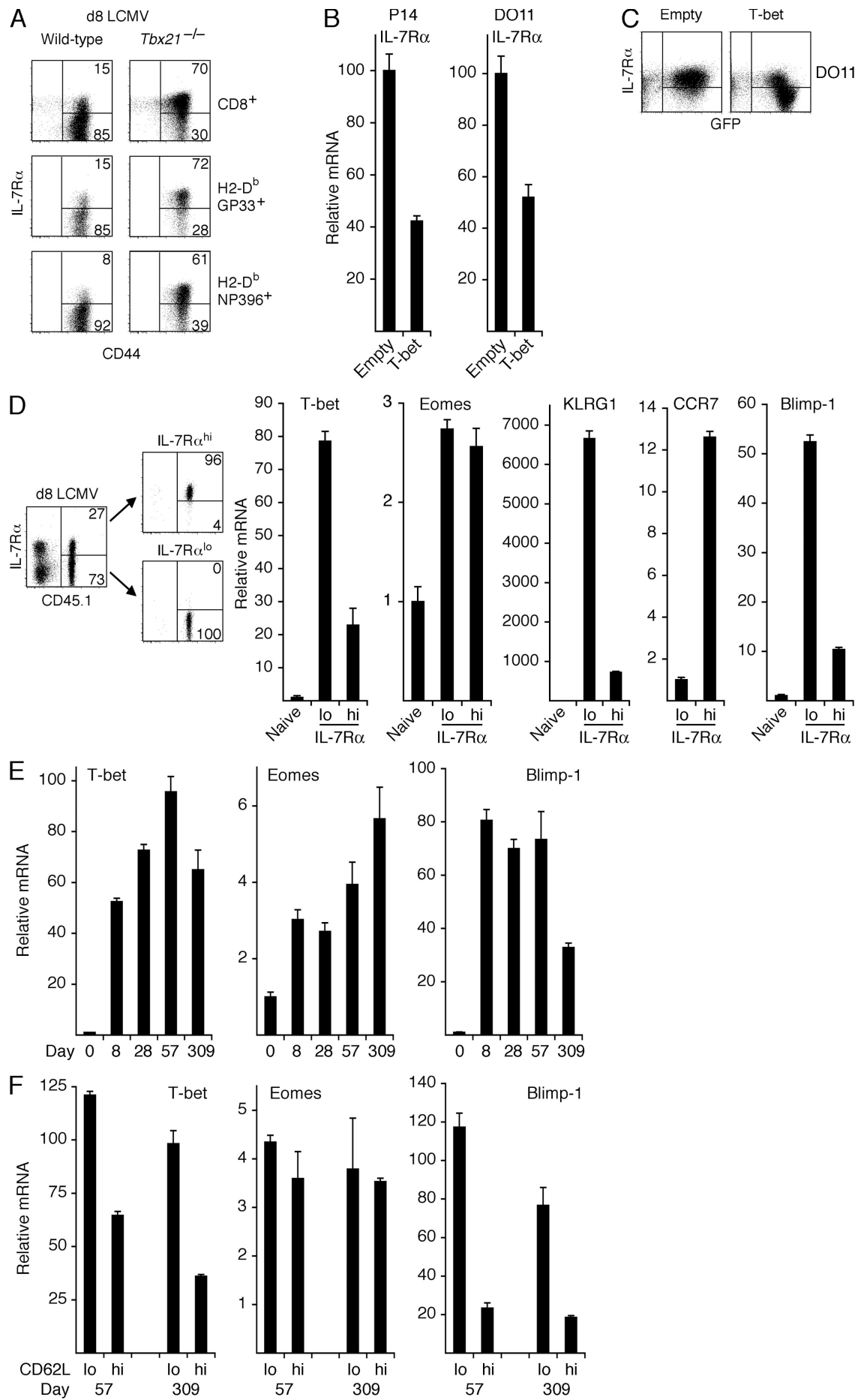

Figure 1. T-bet-mediated repression of IL-7R $\alpha$ in effector CD8 ${ }^{+}$T cells. (A) IL-7R $\alpha$ expression on $C D 8^{+}$T cells from blood of wild-type or Tbx21-1mice $8 \mathrm{~d}$ after LCMV infection. Top row shows CD8 ${ }^{+} \mathrm{T}$ cells; middle and bottom rows show H-2DbGP33+ or H-2DbNP396 ${ }^{+} \mathrm{T}$ cells, respectively; the percentage of events are indicated. (B) Quantitative RT-PCR (Q-PCR) of IL-7R $\alpha$ mRNA from P14 CD8 ${ }^{+}$(left) or D011.10 CD4+ (right) T cells stimulated with peptide plus APCs and transduced with retrovirus. Cells sorted $5 \mathrm{~d}$ after transduction based on GFP. (C) IL-7R $\alpha$ expression on D011.10 CD4+ ${ }^{+}$cells in $T_{H} 2$ conditions stimulated and transduced as in B. Cells stained $5 \mathrm{~d}$ after transduction. (D) Q-PCR of P14 CD8 $8^{+}$T cells from spleens $8 \mathrm{~d}$ after infection sorted for IL-7R $\alpha^{\text {hi }}$ or IL-7R $\alpha^{10}$ expression. Naive (CD44 ${ }^{\circ}$ ) CD8 ${ }^{+}$T cells are included in some graphs for reference. (E and F) 0-PCR of T-bet, Eomes, or Blimp-1 mRNA in LCMV-specific CD8 ${ }^{+}$T cells. $\mathrm{H}_{-2} \mathrm{D}^{\mathrm{b}} \mathrm{GP} 33^{+}$plus $\mathrm{H}-2 \mathrm{D}^{\mathrm{b} N P 396} 6^{+} \mathrm{CD} 8^{+}$T cells sorted from spleens of wild-type mice at the indicated day after infection. Unfractionated tetramer-positive cells (E) or tetramer-positive cells fractionated by CD62 $\mathrm{L}^{\text {hi }}$ or CD62 $\mathrm{L}^{\mathrm{lo}}$ expression (F). Values for Q-PCR represent the mean \pm the SEM of triplicate determinations, normalized to HPRT. All results are representative of at least three experiments. 

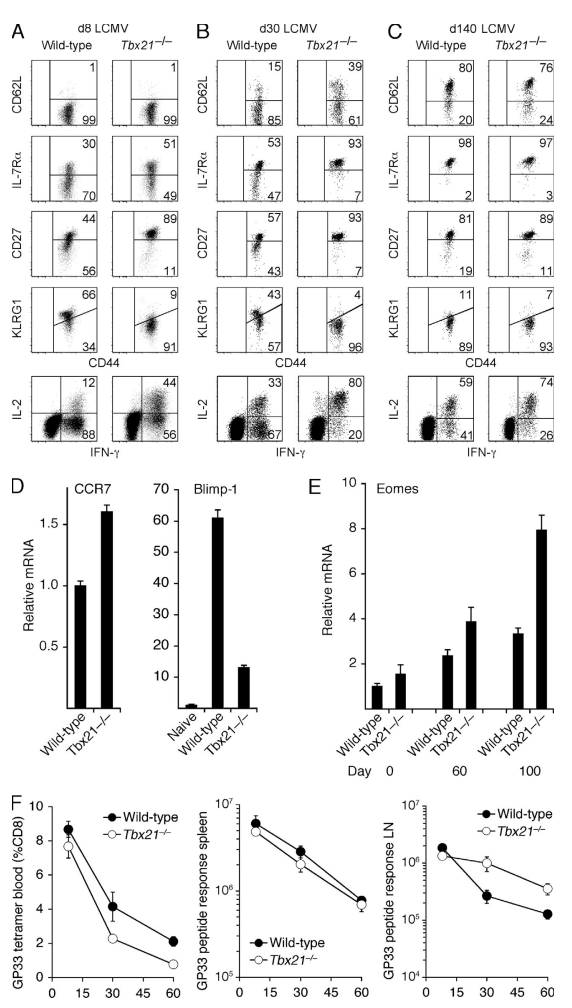

Figure 2. Enhanced generation of central-memory $\mathrm{CD8}^{+} \mathrm{T}$ cells in T-bet-deficient mice. (A-C) Phenotype of GP33-specific CD8 ${ }^{+} T$ cells from spleens of wild-type or Tbx21-1- mice 8 (A), 30 (B), or $140 \mathrm{~d}$ (C) after LCMV infection. Plots display $\mathrm{H}-2 \mathrm{D}^{\mathrm{b}} \mathrm{GP} 33^{+}$events; the percentage of events are indicated. For bottom row, splenocytes were stimulated with $\mathrm{GP}_{33-41}$ peptide; numbers indicate the percentage producing both IFN- $\gamma$ and IL-2. Results are representative of three experiments with multiple mice per time point. ( $D$ and E) Q-PCR of $\mathrm{H}_{-} 2 \mathrm{D}^{\mathrm{b}} \mathrm{GP} 33^{+}$plus $\mathrm{H}-2^{\mathrm{b}} \mathrm{NP} 396^{+}$ $\mathrm{CD}^{+} \mathrm{T}$ cells from spleens of wild-type or Tbx21-1- mice. (D) CCR7 and Blimp-1 mRNA $60 \mathrm{~d}$ after infection. Naive represents $\mathrm{CD} 44^{10} \mathrm{CD} 8^{+} \mathrm{T}$ cells from uninfected wild-type mice. (E) Eomes mRNA 60 and $100 \mathrm{~d}$ after infection. Day 0 represents $C D 44^{\circ} \mathrm{CD} 8{ }^{+} \mathrm{T}$ cells from uninfected wild-type or $T b \times 21^{-1-}$ mice. Results are representative of three similar experiments. (F) Quantification of LCMV-specific CD8 $8^{+}$T cells from wild-type or Tbx21-1mice 8,30 , and $60 \mathrm{~d}$ after infection. Left graph shows $\mathrm{H}_{-}-2 \mathrm{D}^{\mathrm{b}} \mathrm{GP} 33^{+}$cells as the percentage of $\mathrm{CD}^{+}$in blood. Middle and right graphs show numbers of $\mathrm{CD} 8^{+} \mathrm{T}$ cells from spleen or lymph node (pooled axillary, inguinal, cervical, paraaortic, and mesenteric), respectively, producing IFN- $\gamma$ in response to $\mathrm{GP}_{33-41}$. Results represent the mean \pm the $\mathrm{SEM}$ for at least three mice per data point.

at a greater frequency (Fig. 3, A and B). Mice that received Tbx $21^{-1-}$ memory $\mathrm{CD}^{+} \mathrm{T}$ cells also showed substantially reduced bacterial burdens in both spleen and liver compared with recipients of wild-type cells (Fig. 3 C). Thus, deletion of T-bet promotes the development of highly functional memory $\mathrm{CD}^{+} \mathrm{T}$ cells. Presently, we are unsure why the defect in effector-memory $\mathrm{CD}^{+} \mathrm{T}$ cells resulting from deficiency of T-bet appears more permanent in this study compared with prior findings (16), although the operational definitions of effector-memory differ (phenotypic/functional versus chemokine receptor) in the two studies.

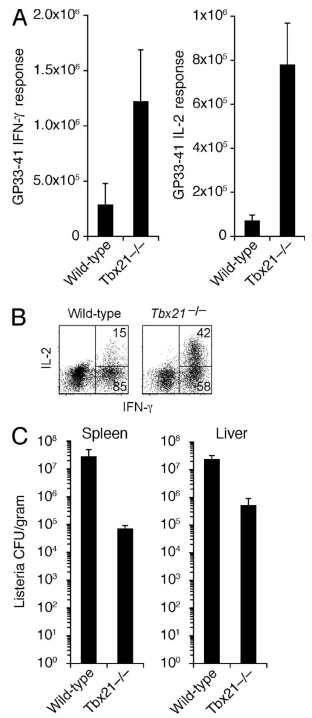

Figure 3. Enhanced secondary expansion and protection of T-betdeficient memory cells. Equal numbers $\left(2 \times 10^{5}\right)$ of wild-type or Tbx21-1GP33-specific CD $8^{+}$T cells (Thy $1.2^{+}$) isolated $45 \mathrm{~d}$ after LCMV infection and transferred to naive wild-type recipients (Thy $\left.1.1^{+}\right) .1 \mathrm{~d}$ after transfer, recipient mice were infected with $2.5 \times 10^{5} \mathrm{CFU}$ of L. monocytogenes. $4 \mathrm{~d}$ after challenge, spleens and livers were harvested to assess CD8 $8^{+} \mathrm{T}$ cell expansion and perform quantitative bacterial cultures. (A) Wild-type or Tbx21-1- GP33-specific CD8 ${ }^{+} \mathrm{T}$ cell expansion. Graphs display numbers of transferred cells (Thy $1.2^{+}$) from spleens of recipient mice producing IFN- $\gamma$ or IL-2 in response to $\mathrm{GP}_{33-41}$. (B) Cytokine production by wild-type or Tbx21-1- GP33-specific CD8 ${ }^{+}$T cells from spleens of recipient mice. Plots display $C D 8^{+}$events; numbers indicate the percentage of cells producing both IFN- $\gamma$ and IL-2 in response to $\mathrm{GP}_{33-41}$. (C) Bacterial load in mice that received wild-type or Tbx21-1- GP33-specific CD8 ${ }^{+} \mathrm{T}$ cells. Spleens and livers were homogenized in 1\% Triton X-100. Bacteria quantified by limiting dilution culture. Data for $A$ and $C$ represent the mean \pm the SEM of six recipients of wild-type and four recipients of $T b \times 21^{-1-}$ cells. Results are representative of three similar experiments.

\section{Dysregulated T-bet expression and impaired central- memory $\mathrm{CD}^{+}{ }^{+} \mathrm{T}$ cell formation in the absence of $\mathrm{CD}^{+}$ T cell help}

A well-characterized model of defective memory $\mathrm{CD}^{+} \mathrm{T}$ cell development involves $\mathrm{CD}^{+} \mathrm{T}$ cell activation in the absence of $\mathrm{CD}^{+} \mathrm{T}$ cell help (21-25). We examined the properties of "unhelped" CD $8{ }^{+} \mathrm{T}$ cells by transfer of $\mathrm{P} 14 \mathrm{CD} 8^{+} \mathrm{T}$ cells into $\mathrm{Cd}^{-1-}$ recipients (Fig. 4) or recipients depleted of $\mathrm{CD}^{+}{ }^{+} \mathrm{T}$ cells using monoclonal antibody injection (Fig. 5, Fig. S3 [available at http://www.jem.org/cgi/content/full/jem.20070841/ DC1], and not depicted). $8 \mathrm{~d}$ after infection, there was no difference in the properties of $\mathrm{P} 14 \mathrm{CD}^{+} \mathrm{T}$ cells in wild-type compared with $C d 4^{-1-}$ hosts (not depicted). Several weeks after infection, however, $\mathrm{P} 14 \mathrm{CD}^{+} \mathrm{T}$ cells from $\mathrm{Cd} 4^{-/-}$hosts began to manifest signs of aberrant memory differentiation, with impaired expression of CD62L, IL-7R $\alpha$, CD27, and IL-2, and elevated expression of KLRG1 (Fig. 4 A).

The memory cells arising in the absence of $\mathrm{CD}^{+} \mathrm{T}$ cell help appeared to be more effector-memory-like, thus contrasting with $\mathrm{T}$-bet-deficient memory $\mathrm{CD}^{+} \mathrm{T}$ cells, which 

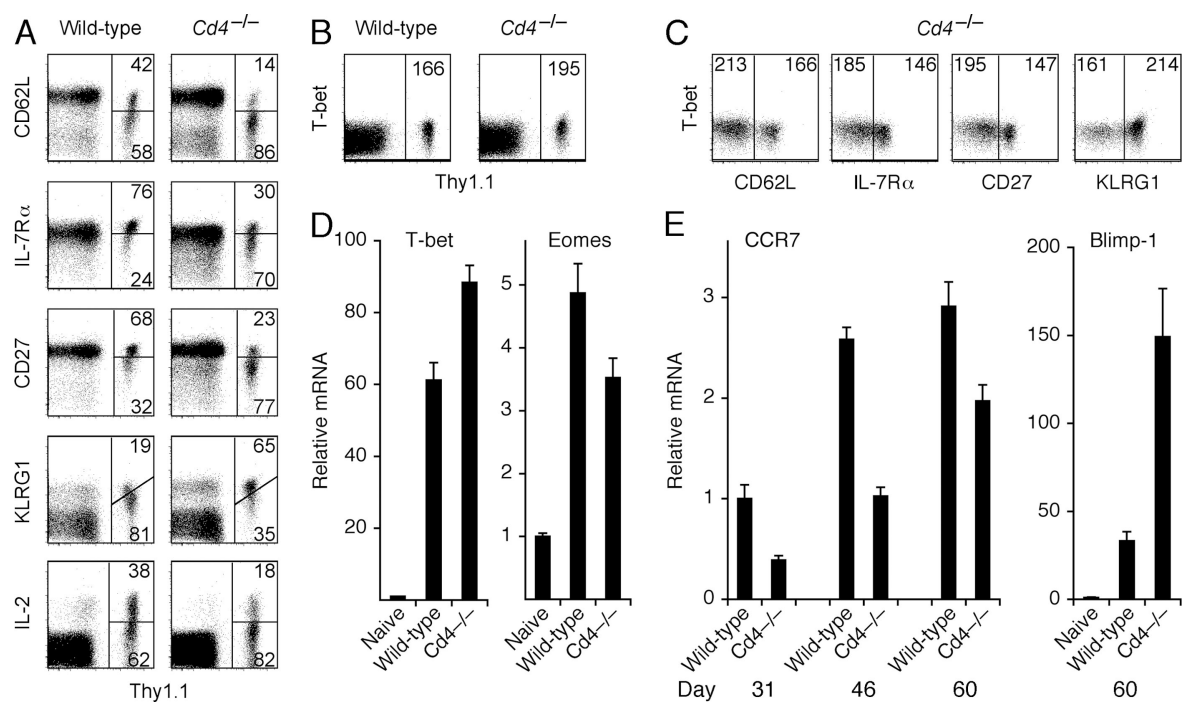

Figure 4. Enhanced T-bet expression in unhelped memory CD8 ${ }^{+}$T cells. (A) Phenotype of P14 cells from wild-type or Cd4 $4^{-1-}$ hosts $60 \mathrm{~d}$ after infection. For bottom row, splenocytes were stimulated with $\mathrm{GP}_{33-41}$. Plots show $\mathrm{CD} 8^{+}$events; numbers indicate the percentage of $\mathrm{P} 14$ cells $\left(\mathrm{Thy} 1.1^{+}\right.$) expressing indicated surface marker or cytokine. (B and C) Intranuclear T-bet staining of P14 cells from wild-type or Cd4 $4^{-1-}$ hosts $75 \mathrm{~d}$ after infection.

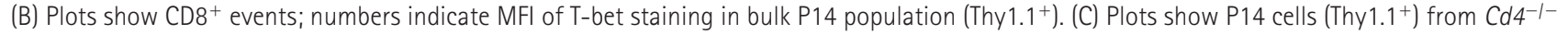
hosts; numbers represent MFI of T-bet staining in subsets with high or low expression of indicated marker. (D) Q-PCR of T-bet and Eomes mRNA in P14 cells from wild-type or Cd4 $4^{-1-}$ hosts $60 \mathrm{~d}$ after infection. (E) Q-PCR of CCR7 and Blimp1 mRNA in P14 cells from wild-type or Cd4 ${ }^{-1-}$ hosts 31, 46, or $60 \mathrm{~d}$ after infection. Values for Q-PCR represent the mean \pm the SEM of triplicate determinations, normalized to HPRT. All results are representative of at least three experiments.

appear to be more central-memory-like. Using intranuclear staining of the $\mathrm{T}$-bet protein, unhelped memory $\mathrm{CD}^{+} \mathrm{T}$ cells exhibited a detectable increase in expression of T-bet (Fig. 4 B), which specifically localized to the expanded effector-memorylike subset (CD62L ${ }^{\text {lo }}$, IL-7R $\alpha^{\text {lo }}$, CD27 ${ }^{\text {lo }}$, KLRG1 $1^{\text {hi; }}$ Fig. $4 \mathrm{C}$ and Fig. S4, available at http://www.jem.org/cgi/content/ full/jem.20070841/DC1). In addition to exhibiting elevated T-bet mRNA (Fig. 4 D), unhelped memory $\mathrm{CD}^{+} \mathrm{T}$ cells were found to express more Blimp-1 mRNA, but less CCR7 and Eomes mRNA (Fig. 4, D and E). Lack of CD4 ${ }^{+} \mathrm{T}$ cell help, thus, appears to impair central-memory and/or promote effector-memory $\mathrm{CD}^{+} \mathrm{T}$ cell development.

\section{T-bet deletion prevents dysfunctional programming of unhelped memory CD8 ${ }^{+} \mathrm{T}$ cells}

To discriminate whether elevated T-bet expression in unhelped memory $\mathrm{CD}^{+} \mathrm{T}$ cells plays a causal role in, or is simply a consequence of, their altered differentiation, we performed antibody depletion of $\mathrm{CD}^{+} \mathrm{T}$ cells from wild-type or $\mathrm{Tb} \times 21^{-1-}$ mice, followed by infection with LCMV. Again, we found that unhelped memory $\mathrm{CD}^{+} \mathrm{T}$ cells in wild-type mice exhibited a predominance of effector-memory-like cells (CD62L ${ }^{\text {lo }}$, IL-7R $\alpha^{\text {lo }}, \mathrm{CD}_{2} 7^{\mathrm{lo}}$, and KLRG $\left.{ }^{\text {hi }}\right)$, with impaired production of IL-2 and CD40L (Fig. 5, A and B, and Fig. S3). Deletion of T-bet, however, prevented the phenotypic and functional defects associated with the lack of CD $4^{+} \mathrm{T}$ cell help (Fig. 5, Fig. S3, and Fig. S5, available at http://www.jem.org/cgi/ content/full/jem.20070841/DC1), resulting in enhanced generation of central-memory $\mathrm{CD}^{+} \mathrm{T}$ cells, regardless of the availability of $\mathrm{CD}^{+}{ }^{+} \mathrm{T}$ cell help. The rescue was apparent even when T-bet deficiency was confined to antigen-specific $\mathrm{CD}^{+}$ T cells (Fig. S5). Moreover, delayed antagonism of T-bet after unhelped memory $\mathrm{CD}^{+} \mathrm{T}$ cell development was capable of reversing several aspects of their dysfunctional phenotype (Fig. S6). Thus, T-bet appears to be required for the aberrant differentiation of memory $\mathrm{CD}^{+} \mathrm{T}$ cells that occurs in the absence of $\mathrm{CD}^{+}{ }^{+} \mathrm{T}$ cell help.

How T-bet and CD $4^{+} \mathrm{T}$ cells execute their opposing effects on the balance between central-versus effector-memory $\mathrm{CD}^{+} \mathrm{T}$ cells remains to be determined. In several different systems, transcription factors function as intrinsic modulators of self-renewal or terminal differentiation. In B lymphocytes, the transcriptional repressor Blimp-1 promotes terminal differentiation (plasma cell) at the expense of self-renewal (memory B cell) (11). In the Drosophila melanogaster neural stem cells, the homeodomain transcription factor Prospero functions as a similar switch by repressing genes required for self-renewal, such as stem cell and cell-cycle genes, while activating genes involved in terminal differentiation (26). Parallels from other biological systems may help elucidate whether T-bet similarly functions to promote terminal differentiation at the expense of self-renewal, which has been proposed to represent an essential distinction between effector- versus central-memory $\mathrm{CD}^{+} \mathrm{T}$ cells, respectively $(2-7,27)$.

The potential ability of T-bet to switch between two polar states of differentiation may explain numerous aspects of viral pathogenesis. Clonal deletion, for example, could be regarded as a "self-renewal deficiency state," associated 


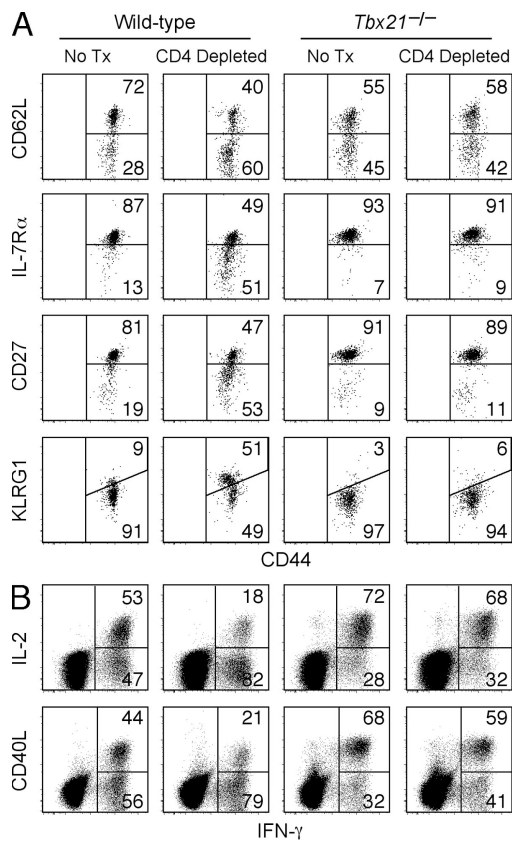

Figure 5. T-bet-dependent dysfunction of unhelped memory CD8 ${ }^{+}$ T cells. (A and B) Wild-type or Tbx21 $1^{-1-}$ mice were left untreated (No Tx) or treated with CD4-depleting antibody (0.2 mg GK1.5 i.p.; CD4 depleted) $1 \mathrm{~d}$ before and $1 \mathrm{~d}$ after LCMV infection. (A) Surface phenotype of GP33-specific $\mathrm{CD}^{+} \mathrm{T}$ cells from spleens $90 \mathrm{~d}$ after infection. Plots show $\mathrm{H}-2 \mathrm{D}^{\mathrm{b}} \mathrm{GP} 33^{+}$ events; numbers represent the percentage of tetramer-positive cells expressing indicated surface marker. (B) Cytokine production of GP33-specific CD8 ${ }^{+} \mathrm{T}$ cells. Plots show $\mathrm{CD} 8^{+}$events; numbers indicate the percentage of cells producing both IFN- $\gamma$ and IL-2 or CD40L in response to $\mathrm{GP}_{33-41}$. Results are representative of two independent experiments.

with extreme excess of T-bet expression resulting from prolonged antigenic stimulation. Likewise, the association of high precursor frequency with enhanced central-memory formation might be considered a "disorder of excessive selfrenewal," explained by diminished T-bet expression as a consequence of excessive competition for antigen (5). The potential role of T-bet in these processes is currently being investigated.

The excessive differentiation of effector-memory $\mathrm{CD} 8^{+}$ $\mathrm{T}$ cells in the absence of $\mathrm{CD} 4^{+} \mathrm{T}$ cell help could involve direct effects, such as loss of soluble or membrane-bound signals typically delivered by $\mathrm{CD} 4^{+} \mathrm{T}$ cells to dendritic cells or $\mathrm{CD}^{+} \mathrm{T}$ cells, including IL-2, chemokines, or CD40L (28-30). Alternatively, loss of $\mathrm{CD}^{+} \mathrm{T}$ cell help could act more indirectly, for example, by altering kinetics of pathogen clearance and necessitating prolonged effector function (3). Although the abnormalities arising in the absence of $\mathrm{CD}^{+} \mathrm{T}$ cell help appear to be at least partially T-bet-dependent, it is anticipated there could be T-bet-independent derangements contributing to the aberrant differentiation of unhelped memory $\mathrm{CD}^{+} \mathrm{T}$ cells. Nonetheless, antagonism of T-bet might represent a novel therapeutic approach for preventing the dysfunctional programming of $\mathrm{CD} 8^{+} \mathrm{T}$ cells in patients with compromised $\mathrm{CD}^{+} \mathrm{T}$ cell function.

\section{MATERIALS AND METHODS}

Mice and pathogens. Mice were maintained and used in accordance with the University of Pennsylvania Institutional Animal Care and Use Guidelines. Wild-type C57BL/6, Tbx21-1- (18), DO11.10 TCR transgenic, and P14 TCR transgenic mice were housed in specific pathogen-free conditions before use. Tb $\times 21^{-1-} \mathrm{P} 14$ TCR transgenic mice were generated by interbreeding $T b \times 21^{-1-}$ mice with P14 transgenic mice. For analysis of the endogenous $\mathrm{CD}^{+} \mathrm{T}$ cell response, C57BL/6 mice or $\mathrm{Tb} \times 21^{-/-}$were infected with $2 \times 10^{5}$ PFU of LCMV Armstrong. H-2D ${ }^{\mathrm{b}} \mathrm{GP} 33$ or $\mathrm{H}-$ $2 D^{\mathrm{b} N P 396}$ tetramers were used to identify LCMV-specific CD8 ${ }^{+} \mathrm{T}$ cells. For P14 transfer experiments, $\sim 5 \times 10^{4} \mathrm{CD}^{+} \mathrm{T}$ cells from naive P14 TCR transgenic mice (Thy1.1/1.1) were transferred intravenously into C57BL/6 or $C d 4^{-/-}$recipients (Thy1.2/1.2). For P14 cotransfer experiments, $\sim 5 \times 10^{4}$ wild-type P14 cells (Thy1.1/1.1) were mixed with $\sim 5 \times 10^{4} \mathrm{~Tb} \times 21^{-1-}$ P14 cells (Thy1.1/1.2) and transferred to wild-type C57BL/6 recipients (Thy1.2/1.2). $1 \mathrm{~d}$ after transfer, recipient mice were infected with LCMV. For CD4 depletion experiments, wild-type or $T b \times 21^{-1-}$ mice received intraperitoneal injection of GK1.5 antibody (0.2 mg in PBS) $1 \mathrm{~d}$ before and $1 \mathrm{~d}$ after infection with LCMV. GK1.5 treatment resulted in efficient depletion of $\mathrm{CD} 4^{+} \mathrm{T}$ cells for $>1 \mathrm{wk}$ (not depicted). For Listeria monocytogenes experiments, mice were challenged with $2.5 \times 10^{5} \mathrm{CFU}$ of $L$. monocytogenes with transgenic expression of the LCMV-derived peptide $\mathrm{GP}_{33-41} .4 \mathrm{~d}$ after bacterial challenge, spleens and livers were homogenized in 1\% Triton X-100 in PBS, followed by limiting dilution culture on blood heart infusion agar.

Flow cytometry, cell culture, stimulation, and retroviral transduction. Surface staining, intracellular cytokine staining, and flow cytometry were performed as previously described (18). For LCMV-derived peptide stimulations, splenocytes or lymph node cells were stimulated for $6 \mathrm{~h}$ with $0.2 \mu \mathrm{g} / \mathrm{ml} \mathrm{GP}{ }_{33-41}$ or $\mathrm{NP}_{396-404}$ peptide in the presence of $1 \mu \mathrm{g} / \mathrm{ml}$ brefeldin A. Antibodies used for flow cytometry were purchased from BD Biosciences. Intranuclear T-bet staining (Santa Cruz Biotechnology) was performed by fixation with $4 \%$ paraformaldehyde in PBS, followed by permeabilization and staining in $0.1 \%$ Triton X-100 and $1 \%$ FBS in PBS. Splenocytes from DO11.10 or P14 TCR transgenic mice were stimulated and transduced as previously described (18).

Quantitative RT-PCR. RNA extraction, cDNA synthesis, and quantitative real-time RT-PCR were performed as previously described (18). Primer and probe sets used for HPRT and Eomes detection were previously described (18). Presynthesized Taqman Gene Expression Assays (Applied Biosystems) were used to amplify the following sequences (gene symbols and Applied Biosystems primer set numbers in parentheses): Blimp-1 (Prdm1; Mm00476128_m1), CCR7 (Ccr7; Mm01301785_m1), KLRG1 (Klrg1; Mm00516879_m1), and T-bet (Tbx21; Mm00450960_m1). 'Test' gene values are expressed relative to that of HPRT, with the lowest experimental value standardized at 1 .

Online supplemental material. Fig. S1 shows that T-bet-deficient antigenspecific memory $\mathrm{CD}^{+} \mathrm{T}$ cells preferentially accumulate in lymph nodes. Fig. S2 shows that T-bet represses central-memory development in a CD8 ${ }^{+}$ $\mathrm{T}$ cell-intrinsic manner. Fig. S3 shows that deletion of T-bet rescues the phenotype and function of unhelped memory $\mathrm{CD}^{+} \mathrm{T}$ cells. Fig. S4 shows that unhelped memory $\mathrm{CD}^{+} \mathrm{T}$ cells have elevated expression of T-bet. Fig. S5 shows that $\mathrm{T}$-bet deficiency restricted to antigen-specific CD8 ${ }^{+} \mathrm{T}$ cells is capable of correcting abnormalities associated with unhelped memory cells. Fig. S6 shows that preexisting dysfunction in unhelped memory $\mathrm{CD}^{+} \mathrm{T}$ cells can be reversed by antagonism of T-bet. The online version of this article is available at http://www.jem.org/cgi/content/full/jem.20070841/DC1.

We are grateful to E. Allenspach, J. Chang, C. DeJong, D. Knoblock, S. Gordon, I. Kinjyo, A. O'Hara, V. Palanivel, H. Shin, and K. Vinup for assistance and discussion. These studies were supported by National Institutes of Health grants (Al042370, Al061699, Al071309, and Al007532) and the Abramson Family Cancer Research Institute.

The authors have no conflicting financial interests. 
Submitted: 25 April 2007

Accepted: 24 July 2007

\section{REFERENCES}

1. Williams, M.A., and M.J. Bevan. 2007. Effector and memory CTL differentiation. Annu. Rev. Immunol. 25:171-192.

2. Sallusto, F., D. Lenig, R. Forster, M. Lipp, and A. Lanzavecchia. 1999. Two subsets of memory $\mathrm{T}$ lymphocytes with distinct homing potentials and effector functions. Nature. 401:708-712.

3. Wherry, E.J., V. Teichgraber, T.C. Becker, D. Masopust, S.M. Kaech, R. Antia, U.H. von Andrian, and R. Ahmed. 2003. Lineage relationship and protective immunity of memory CD8 T cell subsets. Nat. Immunol. $4: 225-234$.

4. Manjunath, N., P. Shankar, J. Wan, W. Weninger, M.A. Crowley, K. Hieshima, T.A. Springer, X. Fan, H. Shen, J. Lieberman, and U.H. von Andrian. 2001. Effector differentiation is not prerequisite for generation of memory cytotoxic T lymphocytes. J. Clin. Invest. 108:871-878.

5. Marzo, A.L., K.D. Klonowski, A. Le Bon, P. Borrow, D.F. Tough, and L. Lefrancois. 2005. Initial T cell frequency dictates memory CD8+ T cell lineage commitment. Nat. Immunol. 6:793-799.

6. Chang, J.T., V.R. Palanivel, I. Kinjyo, F. Schambach, A.M. Intlekofer, A. Banerjee, S.A. Longworth, K.E. Vinup, P. Mrass, J. Oliaro, et al. 2007. Asymmetric $\mathrm{T}$ lymphocyte division in the initiation of adaptive immune responses. Science. 315:1687-1691.

7. Kaech, S.M., J.T. Tan, E.J. Wherry, B.T. Konieczny, C.D. Surh, and R. Ahmed. 2003. Selective expression of the interleukin 7 receptor identifies effector CD8 T cells that give rise to long-lived memory cells. Nat. Immunol. 4:1191-1198.

8. Huster, K.M., V. Busch, M. Schiemann, K. Linkemann, K.M. Kerksiek, H. Wagner, and D.H. Busch. 2004. Selective expression of IL-7 receptor on memory $\mathrm{T}$ cells identifies early CD40L-dependent generation of distinct CD8+ memory T cell subsets. Proc. Natl. Acad. Sci. USA. 101:5610-5615.

9. Voehringer, D., C. Blaser, P. Brawand, D.H. Raulet, T. Hanke, and H. Pircher. 2001. Viral infections induce abundant numbers of senescent CD8 T cells. J. Immunol. 167:4838-4843.

10. Robbins, S.H., M.S. Tessmer, L. Van Kaer, and L. Brossay. 2005. Direct effects of T-bet and MHC class I expression, but not STAT1, on peripheral NK cell maturation. Eur. J. Immunol. 35:757-765.

11. Lin, Y., K. Wong, and K. Calame. 1997. Repression of c-myc transcription by Blimp-1, an inducer of terminal B cell differentiation. Science. 276:596-599.

12. Kallies, A., E.D. Hawkins, G.T. Belz, D. Metcalf, M. Hommel, L.M. Corcoran, P.D. Hodgkin, and S.L. Nutt. 2006. Transcriptional repressor Blimp-1 is essential for T cell homeostasis and self-tolerance. Nat. Immunol. 7:466-474.

13. Martins, G.A., L. Cimmino, M. Shapiro-Shelef, M. Szabolcs, A. Herron, E. Magnusdottir, and K. Calame. 2006. Transcriptional repressor Blimp-1 regulates $\mathrm{T}$ cell homeostasis and function. Nat. Immunol. 7:457-465.

14. Chtanova, T., R. Newton, S.M. Liu, L. Weininger, T.R. Young, D.G. Silva, F. Bertoni, A. Rinaldi, S. Chappaz, F. Sallusto, et al. 2005. Identification of $\mathrm{T}$ cell-restricted genes, and signatures for different $\mathrm{T}$ cell responses, using a comprehensive collection of microarray datasets. J. Immunol. 175:7837-7847.
15. Szabo, S.J., B.M. Sullivan, C. Stemmann, A.R. Satoskar, B.P. Sleckman, and L.H. Glimcher. 2002. Distinct effects of T-bet in TH1 lineage commitment and IFN-gamma production in CD4 and CD8 T cells. Science. 295:338-342.

16. Juedes, A.E., E. Rodrigo, L. Togher, L.H. Glimcher, and M.G. von Herrath. 2004. T-bet controls autoaggressive CD8 lymphocyte responses in type 1 diabetes. J. Exp. Med. 199:1153-1162.

17. Townsend, M.J., A.S. Weinmann, J.L. Matsuda, R. Salomon, P.J. Farnham, C.A. Biron, L. Gapin, and L.H. Glimcher. 2004. T-bet regulates the terminal maturation and homeostasis of NK and Valpha14i NKT cells. Immunity. 20:477-494.

18. Intlekofer, A.M., N. Takemoto, E.J. Wherry, S.A. Longworth, J.T. Northrup, V.R. Palanivel, A.C. Mullen, C.R. Gasink, S.M. Kaech, J.D Miller, et al. 2005. Effector and memory CD8 + T cell fate coupled by T-bet and eomesodermin. Nat. Immunol. 6:1236-1244.

19. Takemoto, N., A.M. Intlekofer, J.T. Northrup, E.J. Wherry, and S.L. Reiner. 2006. Cutting Edge: IL-12 inversely regulates T-bet and eomesodermin expression during pathogen-induced CD8 $+\mathrm{T}$ cell differentiation. J. Immunol. 177:7515-7519.

20. Hwang, E.S., J.H. Hong, and L.H. Glimcher. 2005. IL-2 production in developing Th1 cells is regulated by heterodimerization of RelA and T-bet and requires T-bet serine residue 508. J. Exp. Med. 202:1289-1300.

21. Bevan, M.J. 2004. Helping the CD8(+) T-cell response. Nat. Rev. Immunol. 4:595-602.

22. Janssen, E.M., E.E. Lemmens, T. Wolfe, U. Christen, M.G. von Herrath, and S.P. Schoenberger. 2003. CD4+ T cells are required for secondary expansion and memory in CD8 $+\mathrm{T}$ lymphocytes. Nature. $421: 852-856$

23. Shedlock, D.J., and H. Shen. 2003. Requirement for CD4 T cell help in generating functional CD8 T cell memory. Science. 300:337-339.

24. Sun, J.C., and M.J. Bevan. 2003. Defective CD8 T cell memory following acute infection without CD4 T cell help. Science. 300:339-342.

25. Sun, J.C., M.A. Williams, and M.J. Bevan. 2004. CD4+ T cells are required for the maintenance, not programming, of memory CD8 $+\mathrm{T}$ cells after acute infection. Nat. Immunol. 5:927-933.

26. Choksi, S.P., T.D. Southall, T. Bossing, K. Edoff, E. de Wit, B.E. Fischer, B. van Steensel, G. Micklem, and A.H. Brand. 2006. Prospero acts as a binary switch between self-renewal and differentiation in Drosophila neural stem cells. Dev. Cell. 11:775-789.

27. Luckey, C.J., D. Bhattacharya, A.W. Goldrath, I.L. Weissman, C. Benoist, and D. Mathis. 2006. Memory T and memory B cells share a transcriptional program of self-renewal with long-term hematopoietic stem cells. Proc. Natl. Acad. Sci. USA. 103:3304-3309.

28. Bourgeois, C., B. Rocha, and C. Tanchot. 2002. A role for CD40 expression on $\mathrm{CD} 8+\mathrm{T}$ cells in the generation of CD8 $+\mathrm{T}$ cell memory. Science. 297:2060-2063.

29. Castellino, F., A.Y. Huang, G. Altan-Bonnet, S. Stoll, C. Scheinecker, and R.N. Germain. 2006. Chemokines enhance immunity by guiding naive CD8 + T cells to sites of CD4+ T cell-dendritic cell interaction. Nature. 440:890-895.

30. Williams, M.A., A.J. Tyznik, and M.J. Bevan. 2006. Interleukin-2 signals during priming are required for secondary expansion of CD8+ memory T cells. Nature. 441:890-893. 